\title{
3D MODELLING IN THE REGISTRATION AND RESTORATION OF A MEGALITHIC TOMB
}

\author{
Á. Rodríguez Miranda ${ }^{\text {a }}$, P. Pérez Vidiella ${ }^{\text {a }}$ J. Fernández-Eraso ${ }^{\text {b }}$, J.A. Mujika-Alustiza ${ }^{\text {b }}$, J.M. Valle Melón ${ }^{\text {a }}$ * \\ ${ }^{\text {a }}$ Laboratory for the Geometric Documentation of Heritage (GPAC - Built Heritage Research Group) - University of the Basque \\ Country (UPV/EHU), Vitoria-Gasteiz (Spain) - ldgp@ehu.eus \\ ${ }^{\mathrm{b}}$ Dept. of Geography, Prehistory and Archaeology - University of the Basque Country (UPV/EHU), Vitoria-Gasteiz (Spain) - \\ javier.fernandeze@ehu.eus, joseantonio.mugica@ehu.eus
}

\section{Commission VI, WG VI/4}

KEY WORDS: dolmen, stereoplotting, Structure from Motion (SfM), incremental 3D model, multitemporal 3D model (4D model)

\begin{abstract}
:
This article aims at showing some potential applications of geomatics to works in which both excavation and restoration are carried out simultaneously, so that the three-dimensional layout of the monument undergoes continuous and important changes throughout the intervention. The article offers an overview of several works in geometric documentation and three-dimensional modelling carried out during the archaeological excavations and the restoration of a megalithic monument -dolmen Alto de la Huesera- from 2010 to 2014. The activities described here encompass a wide range of goals, including marking out the excavation grid, the geometric recording of the burials, the three-dimensional modelling of the slabs and the surrounding mound, the virtual visualization and check of possible reconstructions before undertaking actual rearrangements of the components on site as well as the classification and archive of the information so as to maintain the traceability of the tasks accomplished during this period.
\end{abstract}

\section{INTRODUCTION}

As is well known, "restoration" implies the modification of the shape, the displacement of the components and changes to the appearance of the elements of heritage that undergo works. For their part, the techniques for massive data capture (such as photogrammetry or laser scanning) allow for the generation of detailed three-dimensional models that show the state of the monument at different moments, which enables us not only to register each state but also to analyse the changes over time.

These changes can be interpreted from two complementary points of view: on the one hand, they make possible to know the extent of the interventions and executed works during the restoration process (material removal, reconstruction, etc.), thus recording the tasks performed by the different professionals who are working on site; on the other hand, if it is the case that each three-dimensional model can be linked to a specific historical significance, the sequence of models will reproduce the development of the element of heritage over time.

The simplicity of the analyses of the changes in the visible appearance of an element of heritage through a series of threedimensional models will be determined by the characteristics and the nature of the interventions themselves. For instance, when we deal with an archaeological excavation, the process of digging itself makes the successive levels progressively deeper, in such a way that they all can be represented by means of easily understandable stratigraphic columns. On the contrary, there are other cases -such as the subject of this article- in which the simultaneous display of models representing different times will be problematic due to the fully three-dimensional rearrangement of the scene.

More specifically, we refer to the excavation and restoration works that, throughout five campaigns (from 2010 to 2014), were done at a megalithic tomb -dolmen of Alto de la Huesera, located near the town of Laguardia (Álava, Spain), in coordinates $42^{\circ} 34^{\prime} 10^{\prime \prime} \mathrm{N}, 2^{\circ} 33^{\prime} 58^{\prime}$ ' W-. This construction can be dated to the end of the Neolithic or even to the Early Chalcolithic period (between 4200 and 3500 BC), remaining in use until the Intermediate Bronze Age (Fernández Eraso; Mujika Alustiza 2013a). Originally, the dolmen comprised a chamber of around $3 \times 3$ metres in plan view made up by six large slabs up to 3 metres high with another big stone as cover on top. This chamber was accessible through a corridor formed by two parallel lines of smaller vertical slabs, the complete structure being buried under a circular mound. This passage tomb was identified in 1947 by Fernández Medrano (Fernández Medrano, 1948; Barandiaran \& Fernández Medrano, 1959), who excavated the polygonal chamber during the following year.

As told before, from 2010 onwards a new series of excavations over the entire site allowed its demarcation, defined the limits of the burial mound -of around 22 metres in diameter- and brought to the surface an 8 metres long corridor (Fernández Eraso; Mujika Alustiza 2011, 2012, 2013b, 2014). During the excavations, the remains of around 130 individuals were exhumed. Among the recovered materials, artifacts such us an 
abruptly retouched trapezium, ten arrowheads with bifacial plane finishing touches of different morphology, one bronze arrowhead and one bronze graver, as well as some less characteristic pieces (such as one polished stone axe, several lithic flakes -one sickle-, etc.) stand out. As for the pottery, Bell Beaker incise-printed shards and more than one hundred beads can be highlighted.

\section{OBJECTIVES}

The aims that geomatics covered in this project included:

a. Establishing a reference network in an absolute coordinate system.

b. The stakeout of the excavation grid.

c. The documentation and mapping of the material and skeletal remains found during the excavations.

d. Three-dimensional virtual modelling of the state of the site and the visible structures at different times and the generation of different outputs such as plan views, elevations, perspectives, cross-sections, etc., which can represent the accomplished works and assist the task planning for the next steps.

e. The generation of an incremental three-dimensional model that allows assessing the evolution of the works yearly.

f. Visualizing hypotheses of the original appearance of the monument.

g. The archive of the information in order to maintain the traceability of the generated products, thus permitting their re-use over time.

In particular, the three-dimensional models mentioned in points "d", "e" and "f" of the list above are addressed in further detail in the following sections of the text. For these models, the different techniques used for their production as well as the applications of each type are discussed.

\section{DEVELOPMENT}

\subsection{Geomatics for the geometric documentation of dolmens}

Prehistoric megalithic constructions have attracted attention from many points of view and scales of study, which has resulted in the application of a large repertoire of techniques of geometric documentation (surveying with total station, laser scanning, photogrammetry, etc.).

For example, we can find studies concerning their astronomic orientation (Hoskin, 2009; Lozano et al., 2014); their relationship with the landscape and the perception of the territory (Criado \& Mañana, 2003; Enríquez \& Duque, 2015); the characteristics of the burial mound (Arnal \& Balsan, 1980; Moraza et al., 2003; De Blas, 2006; Blanco \& Fabian, 2011); the arrangement of the slabs making up the chamber and the corridor (Baceiredo \& Baceiredo, 2012; Martínez-Torres et al., 2014; Benavides et al., 2016); the degradation of the materials due to atmospheric causes or biodeterioration (Romão \& Rattazzi, 1996; Figueiredo et al., 2008); the documentation and analysis of the engravings and remains of paintings (Bueno et al., 2007; Cassen et al., 2014; Cortón et al., 2015); the archaeological excavations and the documentation of the exhumed remains, both artefacts and burials (Carrière \&
Clottes, 1970; Beguiristain, 2007-2008; Orengo, 2013; Gavilán et al., 2013; Schmitt \& Bizot, 2016). Additionally, there are woks providing integrated studies of megaliths from different perspectives (López \& Mañana, 2013).

The documentation of the monuments is a common procedure before undertaking any kind of work which might modify their appearance (Mañana, 2005; Aboal \& Porto, 2012; Corton et al., 2013), both as a record of the previous form of the site and as part of the background information for the planning of the restoration itself. The geometric modelling of the megaliths is also useful for the study of their structural stability (Navarro et al., 2008; Reinosa \& Romera, 2015), the visualization of the hypothesis concerning the construction process and their appearance in ancient times (López de Calle et al., 2001; Bouillon \& Cassen, 2008; Luján \& Aguilella, 2012; Ledo, 2016), the musealization on-site (Gutiérrez, 2008) as well as the generation of contents for the interactive $3 \mathrm{D}$ visualization and the dissemination via new digital technologies (Caro \& Hansen, 2015).

\subsection{Documentation of the Alto de la Huesera megalithic tomb}

In the year 2010 -before the intervention- the remains of the mound looked like a haphazardly deposit of debris, among which only the top of the slabs of the chamber and the cover (fallen and thrust inside) stood out slightly (see figure 1). During the campaigns of study of the site, the excavation works overlapped with the refurbishment. As a result, while the chamber, the corridor and the mound were being uncovered, different actions were performed which led to the installation or the removal of reinforcement elements, the stockpile and transport of materials, the dismantlement of some parts of the monument and the reconstruction of other parts.

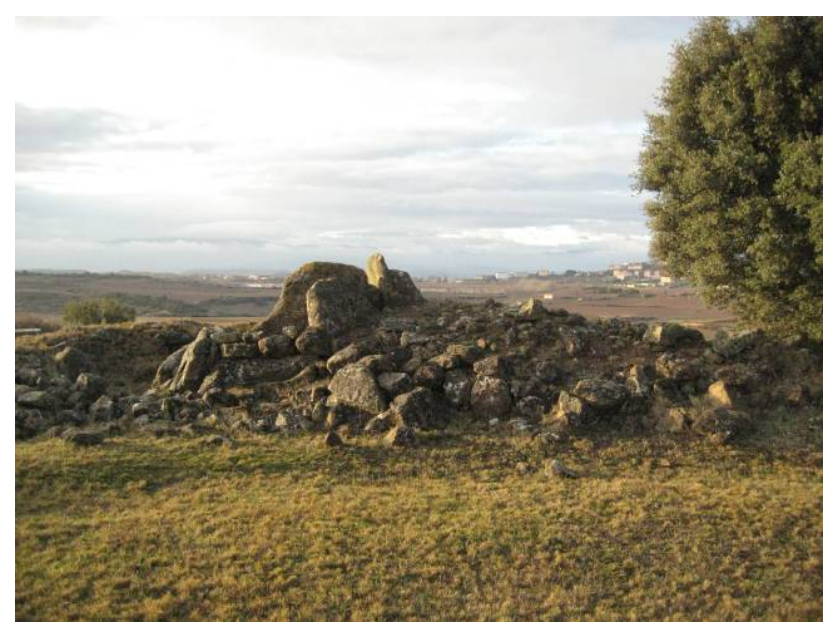

Figure 1. Image of the dolmen in 2010, before undertaking the new series of excavations.

The initial project of geometric documentation used photogrammetric pairs (figure 2), which were subsequently stereoplotted generating a three-dimensional wireframe model (figure 3), and, in a second step, a model of quadrangular meshes (figure 4). In addition, from these three-dimensional models new products such as plan views or cross-sections were derived. This approach was laborious since it required the orientation of the stereopairs and the manual drawing 
(meaningful lines and arrays of points defining the surfaces) by an operator, as well as the individual meshing of the surfaces and the edition of each component of the three-dimensional model. However, at that time, this procedure was deemed adequate given that the slabs of the dolmen were braced with steel support props and wooden planks (elements that we did not want to include in the 3D model), and because of the existence of hidden areas and nooks, in which supervised drawing permits avoiding the undesired elements, filling the gaps and tracking the quality of the results.

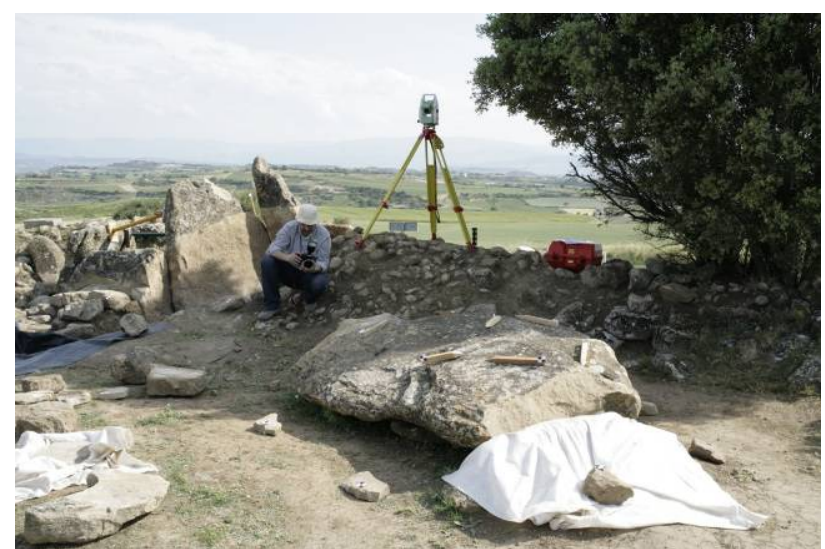

Figure 2. Photogrammetric record by means of stereopairs of the cover slab after its removal from the chamber (July 2010).

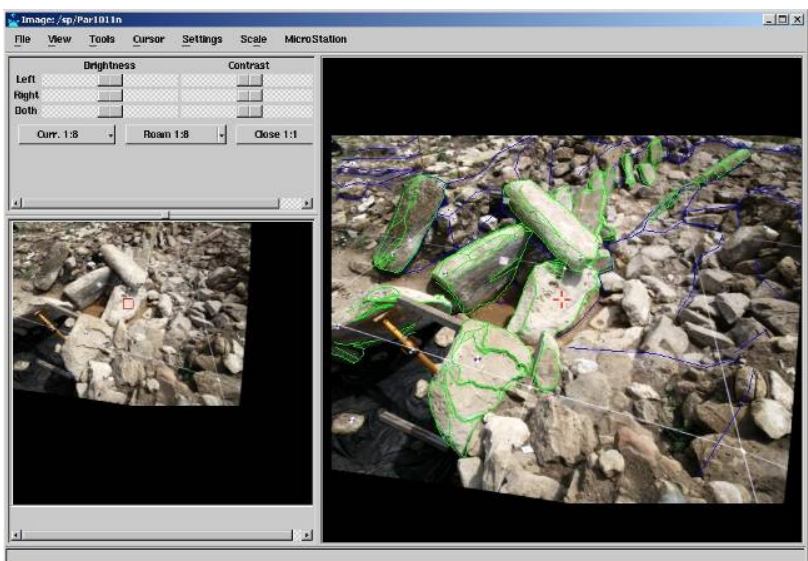

Figure 3. Stereoplotting (line drawing) of a photogrammetric pair.

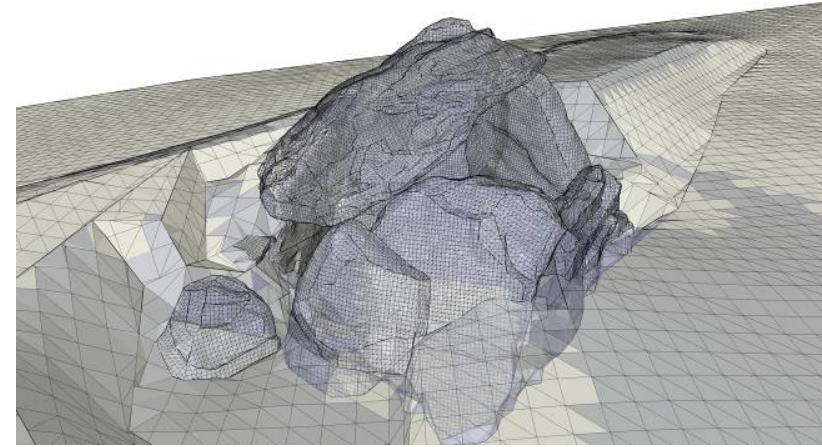

Figure 4. Model of surfaces (January 2011, before the replacement of the cover slab). The size of the meshes is different for the constructive elements $(3 \mathrm{~cm})$ and for the representation of the barrow $(20 \mathrm{~cm})$.
For its part, the intervention period coincided in time with a significant progress in the three-dimensional modelling techniques, namely the market entry -from the year 2012 approximately- of many pieces of software based on SfM (Structure from Motion) algorithms, with the consequent simplification of the procedures for the generation of 3D models from photographs, the greater level of detail of the results and the possibilities given by the automatic texture mapping options and their derivatives such as the orthoimages (figure 5). Around that time, the areas to be documented at the dolmen did no longer include the chamber (whose geometry was not particularly appropriate for SfM processing). Instead, the works focused on the open spaces of the corridor and the upper surface of the mound, which could be documented with a suitable geometry of the shots and within a short period of time (approximately 1 hour to take enough photographs for the complete surface of the mound) by the combination of images taken at ground level and oblique shots with a 4.5 metres high pole (figure 6).

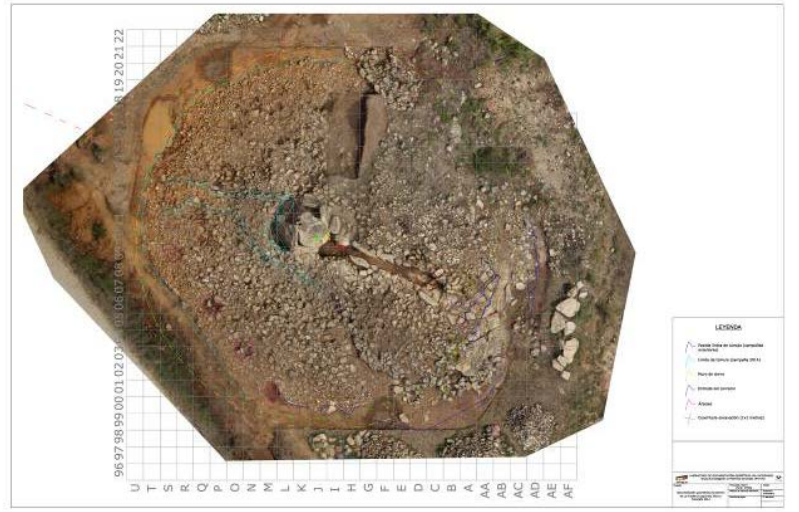

Figure 5. Orthoimage with the line drawing of some relevant archaeological structures superimposed. The layout also shows the excavation grid $(1 \mathrm{x} 1 \mathrm{~m})$ and some hypotheses regarding the original extend of the burial mound.

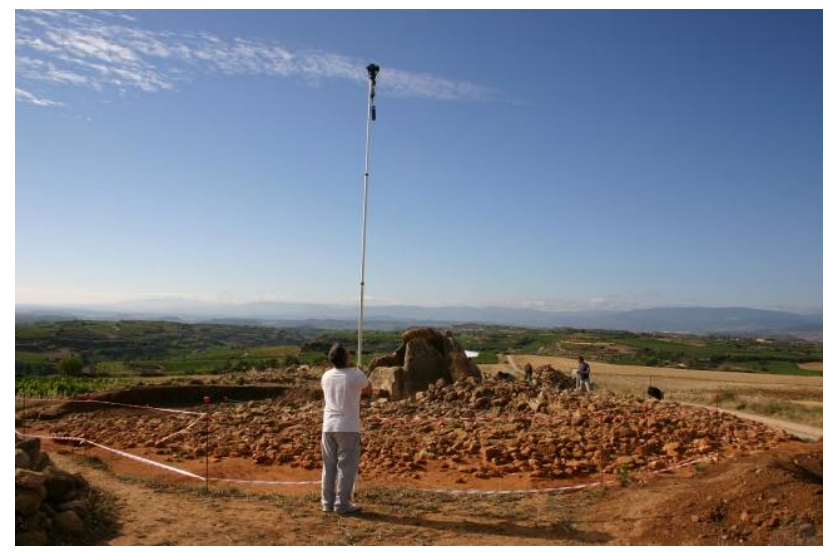

Figure 6. Photographic record (for convergent photogrammetry) of the site from an elevated point of view by means of a camera placed at the top of a pole (year 2014).

Anyway, with the aim of maintaining the continuity of the 3D models of the successive campaigns with the initial one, we carried on taking stereoscopic pairs for every phase, which were 
also orientated and drawn. Indeed, the 3D model generated by stereoplotting has some interesting features which indicate that this technique is applicable in spite of its "handmade" character. For example, the resulting models are rather light and, moreover, both meshes and lines can be easily classified so as to individualize the different components of the monument. Thus, for each new campaign only the changes with respect to the previous one needed to be drawn, thereby generating an incremental three-dimensional model. This multitemporal model lacks photographic texture (unlike the models generated by SfM). Nevertheless, conventional CAD software handles it effortlessly and it is well suited to be used for the design of the following restoration steps in which, for instance, the slabs are virtually relocated according to different alternatives (figure 7).
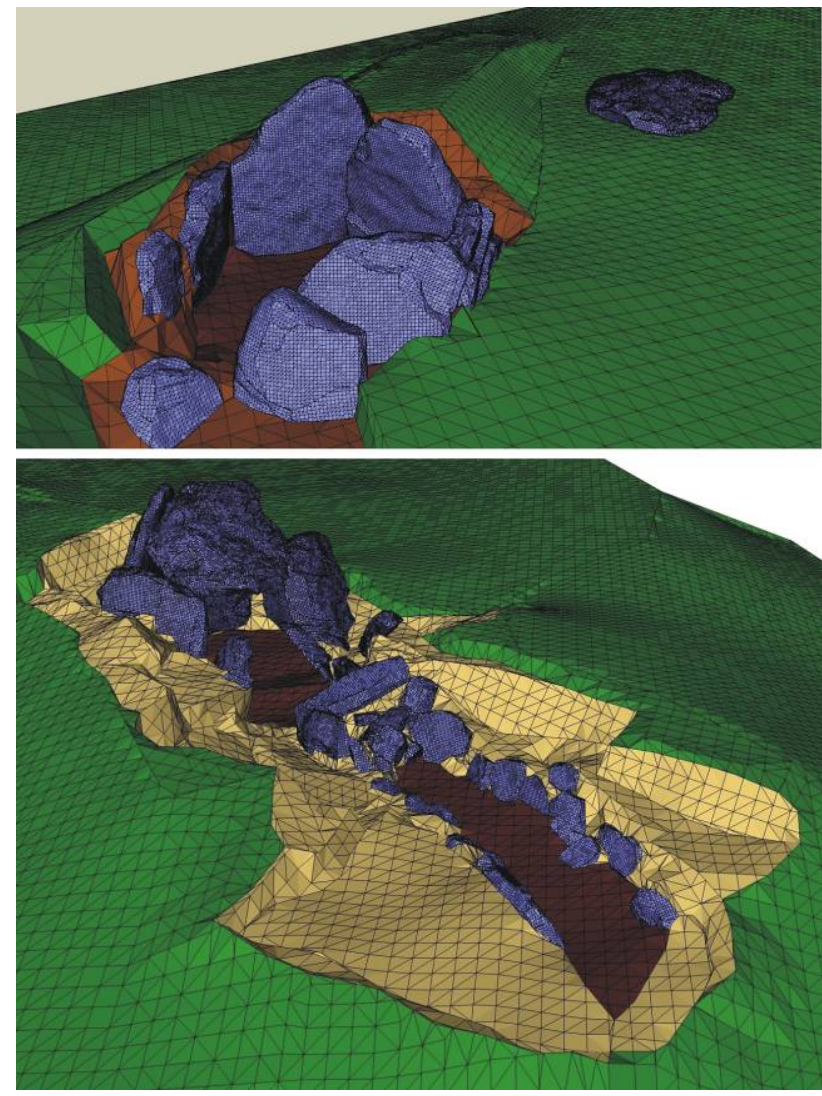

Figure 7. Virtual models showing the evolution of the site.

Above, in 2010 with the stone of the cover removed from the chamber before the excavations. Below, in 2014, with the cover stone replaced on top of the chamber and the barrow partially dismantled.

Indeed, stereoscopy and convergent processing are not incompatible. If needed in the future, as long as the overlap of the stereopairs is large (e.g. 80\%) and care is taken in having varied orientations for the shots -thus providing better intersection angles for the convergent processing-, they could be reprocessed in order to generate three-dimensional models with photographic textures with SfM software (Rodríguez et al., 2015). Although such overlaps are unnecessary for stereoplotting (where values of $60 \%$ are enough), photographs can be taken in a quick and inexpensive manner nowadays, with which it is not a problem to dispose of an overabundance of pictures that we will keep for archival purposes and future reuses, even if, at first, we use only a selection for line drawing.
SfM techniques were also useful for adding to the 3D model the information on the burials excavated inside the chamber and the corridor. For the documentation of the excavations in these areas, the participation of the surveyors was not considered from the beginning; this is why only sketches and some sparse photographs were available as geometric documentation. In this case, by taking the photographs from the archaeological record and using as reference points the marks of the excavation grid and other elements visible on the pictures -such as ranging poles or the lower part of the slabs-, it was possible to generate a series of partial 3D models (figure 8) from which orthoimages were generated in turn. These orthoimages were inserted in the $\mathrm{CAD}$ model and, then, the perimeters of the bones and the material findings were outlined (figure 9).

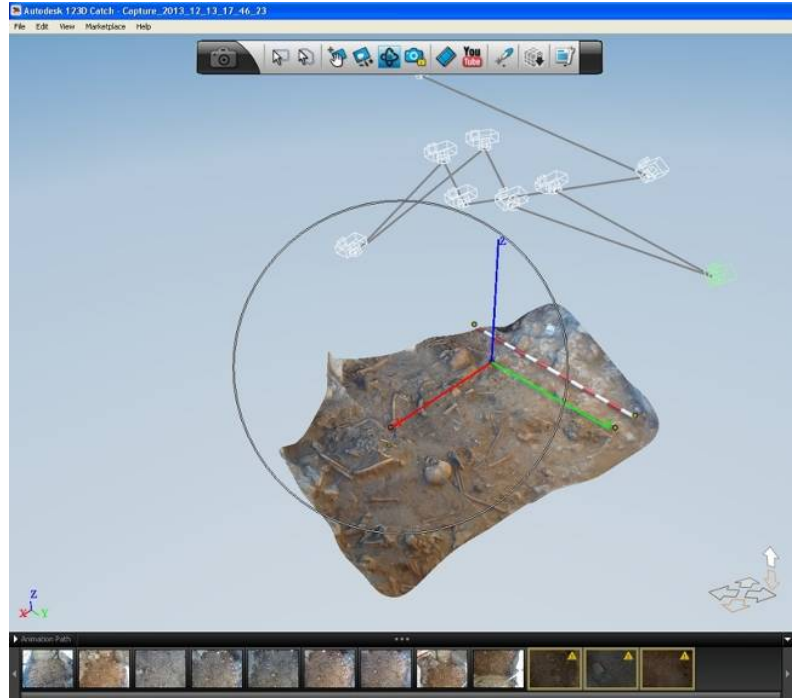

Figure 8. Partial 3D model generated from the pictures taken during the excavation of the burials (software Autodesk 123DCatch $\left.{ }^{\circledR}\right)$.

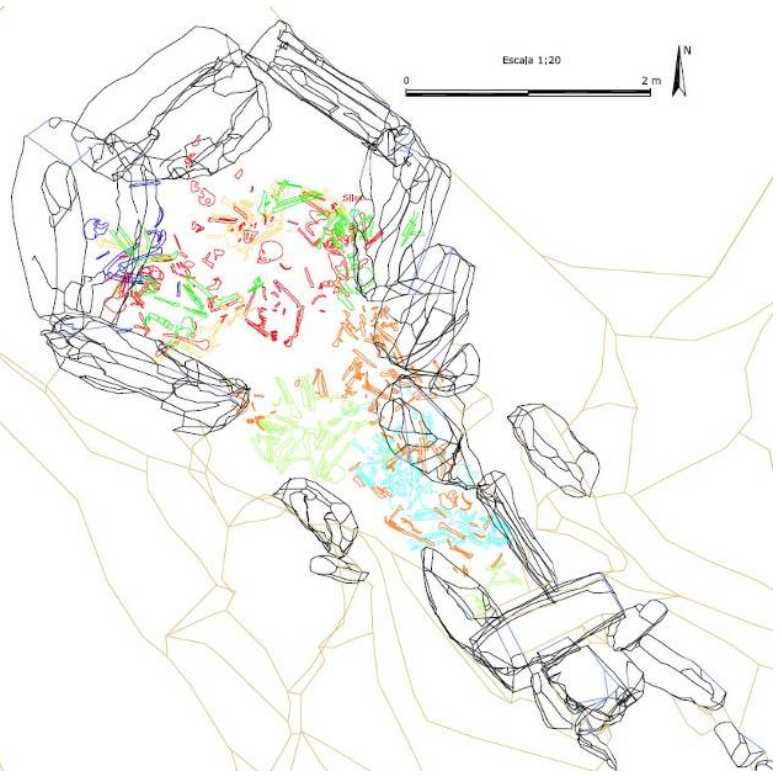

Figure 9. Drawing of the skeletal remains, together with the outline of the slabs (the cover is not represented in order to make the layout clearer). Colours identify bones visible at different times of the excavation. 
This work was time-consuming since the skeletons did not lay in clearly differentiated strata but they appeared in a continuous layer in which the different remains of the individuals were superimposed. As a result, it was difficult to take series of photographs showing exactly the same moment of the excavation -without changes in the arrangement of the scenelarge enough to be computed by means of SfM techniques. In total, ten partial 3D models were generated with the aim of giving a complete coverage of the excavated area both in extension and stratigraphy.

\section{RESULTS}

As has been said in the previous sections, the results of this research include:

1. The collection of registers, that is to say, the photographs gathered in stereoscopic pairs and groups for convergent processing concerning each campaign. Pictures were conveniently classified and their descriptions enriched with Exif and IPTC metadata (Valle \& Rodríguez, 2010), thus allowing for a better information management.

2. Three-dimensional wireframe CAD model $-3 \mathrm{D}$ lines and surfaces without texture- obtained by means of stereoplotting of the photogrammetric pairs, digitization over the orthoimages and direct capture with the total station. In this model, elements are classified and form a single incremental set which guarantees the recreation of the different moments of the excavation, as well as the virtual modification of the position of the elements in order to visualize hypotheses regarding the original arrangement of the slabs or planning restoration works. From this 3D model, different kinds of outputs such as plan views, cross sections, perspective views of developments (figure 10) have been generated.

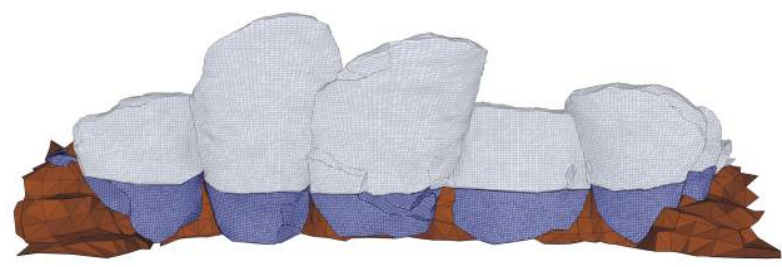

Figure 10. Example of outcome from the multitemporal meshed model: development of the slabs which form the chamber after their projection on a cylinder with a diameter of 3 metres. Light colour represents the visible parts at the beginning of the works, whereas full colours show the parts discovered during first year's excavations.

3. A sequence of models with photographic texture generated by means of convergent photogrammetry (SfM), representing the different appearances of the site at each stage of the simultaneous processes of excavation and restoration. Apart from the use for three-dimensionally visualizing the site at any given moment (figure 11), these models are the basis for the generation of orthoimages that can be added to the line maps and obtaining dissemination products (figure 12).

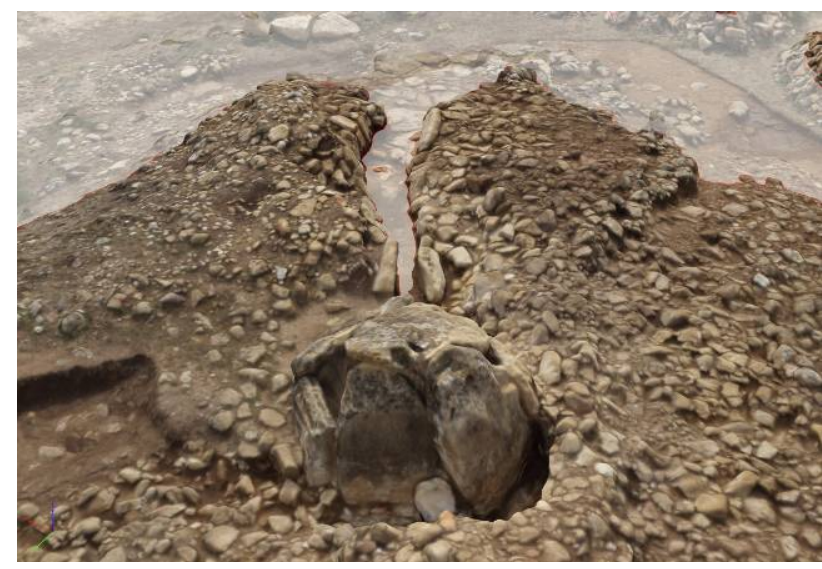

Figure 11. Three-dimensional model with photographic textures (year 2014). Perspective rear view with the indication of a contour line limiting the part of the barrow above the floor of the corridor.

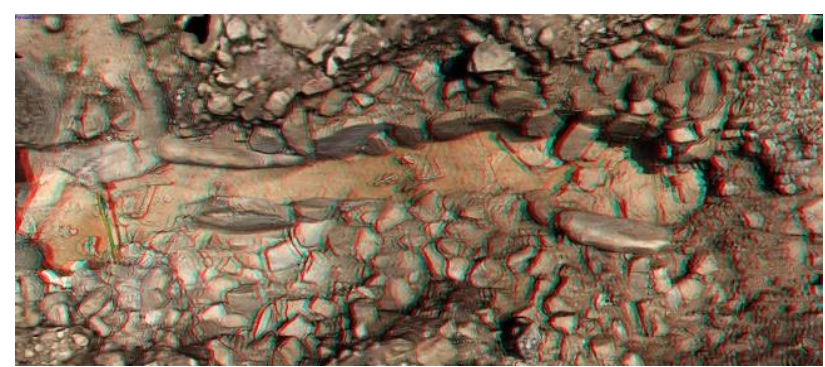

Figure 12. Red-cyan anaglyph of a top view of the corridor, generated from the 3D model with photographic texture.

\section{DISCUSSION}

Although not directly related to the survey work, it is worth mentioning that, at the end of the referred period, important disagreements arose between the archaeologists and the administration in charge of the maintenance of the monument regarding the final appearance of the megalith once reconstructed. In this conflict, historical and scientific values collided with the interests of giving an aesthetical appearance and ensuring the safety of the structure.

This situation highlighted the importance of the documentation as the only way to reinterpret an archaeological site once its configuration has changed completely.

Moreover, whilst it is true that only one option can be chosen for the physical reconstruction of the site, three-dimensional virtual models are a powerful tool for showing alternative and/or augmented versions, including the evolution over time.

\section{CONCLUSIONS}

To summarize, this article has dealt with the applicability of series of three-dimensional models for the monitoring of the excavation and restoration works by focusing on the specific 
case of a megalithic tomb. The main topics of the article include the selection of the most suitable techniques for the geometric documentation as well as the need (and the challenge) to maintain the continuity of the sequence of models in such a way that it encompasses the whole duration of the works or the progressive incorporation of new technological possibilities in projects for several years.

A comparison has also been made between the 3D models with photographic textures that can be generated quickly and in an efficient way by means of techniques of convergent photogrammetry and the models obtained through the intervention of an operator (in this case using stereoplotting).

Production time and cost are favourable factors for the former, while it offers a realistic view of the elements thanks to the incorporation of photographic texture, which also permits to generate derivatives of great interest (e.g. orthoimages). Nevertheless, the models generated automatically by SfM are not interpreted. Therefore, although several of them can be visualized simultaneously, the comparisons that can be done are limited, to a great extent, to the visual analysis or the realization of some basic geometric calculations (such as computing the distances between models). On the contrary, in the model generated through stereoplotting, each construction element appears individualized, which allow us to process them, for instance, by selecting the parts selected for visualization in the virtual environment or the prospective appearance of the monument following the rearrangement of the slabs.

These considerations also apply to any model generated automatically, regardless of whether it has been created by means of SfM or through another technique (for example, laser scanning). The same goes for the interpreted model that, in this case, was generated through stereoplotting but that, in other cases, can be obtained, for instance, by using a BIM (Building Information Modelling) approach.

\section{ACKNOWLEDGEMENTS}

The excavations were funded by the Diputación Foral de ÁlavaArabako Foru Aldundia and were part of the activities of the Research Group IT622-13, recognised by the Basque Government.

\section{REFERENCES}

Aboal, R.; Porto, Y., 2012. Intervencións de conservación e recuperación no xacemento de Forno dos Mouros (Toques, A Coruña). Report CAPA 31, CSIC-Incipit. Santiago de Compostela, Spain. (http://hdl.handle.net/10261/45081)

Arnal, J.; Balsan, L., 1980. Les long tumulus à dolmen décentré du département de l'Aveyron. Gallica préhistoire, 23(1), pp. 183-207.

Baceiredo, V.; Baceiredo, D., 2012. Lienzos del Salón de Abd al-Rahman III Madinat al-Zahra (Córdoba) y dolmen de Menga en Antequera (Málaga), experiencias sobre digitalización 3D y divulgación de la documentación gráfica obtenida. VAR (Virtual Archaeology Review), 3(5), pp. 131-136.
Barandiaran, J.M.; Fernández Medrano, D. 1959 Excavaciones en Álava. Boletín de la Institución Sancho el Sabio, año III, Tomo III, N $11-2$.

Benavides, J.A.; Aranda, G.; Sánchez, M.; Alarcón, E.; Fernández, S.; Lozano, A.; Esquivel, J.A., 2016. 3D modelling in archeology: the application of Structure from Motion methods to the study of the megalithic necrópolis of Panoria (Granada, Spain). Journal of Archaeological Science: Reports, 10 , pp. 495-506.

(doi: http://dx.doi.org/10.1016/jasrep.2016.11.022)

Beguiristain, M.A., 2007-2008. Un singular acondicionamiento del espacio interno en el dolmen de Aizibita (Cirauqui, Navarra). Veleia, 24-25(2), pp. 703-722.

Blanco, A.; Fabián, J.F., 2011. ¿Monumentos evocativos? Los túmulos de Los Tiesos (Mediana de Voltoya, Ávila) en su contexto prehistórico. Munibe (Antropología-Arkeologia), 62, pp. 251-282.

Bouillon, C.; Cassen, S., 2008. De l'Airbus A380 au site néolithique de la Table des Marchands (Morbilan): limites et perspectives d'un transfert de technologie. Archéovision, 3, pp, 158-164.

Bueno, P.; de Balbín, R.; Barroso, R., 2007. Chronologie de l'art mégalithique ibérique: $\mathrm{C}^{14}$ et contextes archéologiques.. L'Anthropologie, 111, pp. 590-654.

(doi: http://dx.doi.org/10.1016/j.anthro.2007.07.006)

Caro, J.L.; Hansen, S., 2015. De la fotogrametría a la difusión del patrimonio arqueológico mediante game engines: Menga un caso de estudio. VAR (Virtual Archaeology Review), 6(12), pp. 58-68. (doi: http://dx.doi.org/10.4995/var.2015.4159)

Carrière, M.; Clottes, J., 1970. Le dolmen du Pench $\mathrm{n}^{0} 1$ à Alvignac (Lot). Gallia préhistoire, 13(1), pp. 109-149.

Cassen, S.; Lescop, L.; Grimaud, V.; Robin, G., 2014. Complementarity of acquisition techniques for the documentation of Neolitic engravings: lasergrammetric and photographic recording in Gravrinis passage tomb (Brittany, France). Journal of Archaeological Science, 45, pp. 126-140. (doi: http://dx.doi.org/10.1016/j.jas.2014.02.019)

Corton, N.; Carrera, F.; Mañana-Borrazás, P.; Seoane-Veiga, Y., 2013. Non-invasive recording technologies for the study and conservation of prehistoric rock art: The Dolmen of Dombate. In: Science and Technology for the Conservation of Cultural Heritage. Taylor \& Francis, London, pp. 159-162.

Cortón, N.; López, Á.; Carrera, F., 2015. Combining photogrammetry and photographic enhancement techniques for the recording of megalithic art in north-west Iberia. Digital Applications in Archaeology and Cultural Heritage, 2, pp. 89101. (doi: http://dx.doi.org/10.1016/j.daach.2015.02.004)

Criado, F.; Mañana, P., 2003. Arquitectura como materialización de un concepto. La espacialidad megalítica. Arqueología de la Arquitectura, 2, pp. 103-111.

(http://hdl.handle.net/10261/6851)

De Blas, M.A., 2006. La arquitectura como fin de un proceso: una revisión de la naturaleza de los túmulos prehistóricos sin cámaras convencionales en Asturias. Zephyrus, 59, 233-255. 
Enriquez, J.J.; Duque D.M., 2015. El dolmen del Milano y la articulación territorial del fenómeno megalítico en el área de Barcarrota (Badajoz). Zephyrus, LXXXV, pp. 85-105. (doi: http://dx.doi.org/10.14201/zephyrus20157585105)

Fernández Eraso, J.; Arévalo-Muñoz, E.; Camarero-Arribas, Cr.; Garcías-Díez, M.; Ochoa-Fraile, B.; Mujika-Alustiza, J.A., 2016. Estela decorada en el dolmen del Alto de la Huesera (Laguardia, Álava). Zephyrus LXXVIII, 19-33.

(doi: http://dx.doi.org/10.14201/zephyrus2016781933)

Fernández Eraso, J.; Mujika-Alustiza, J.A., 2011. Dólmenes de La Rioja Alavesa: El Montecillo (Villabuena de Álava), Chabola de la Hechicera (Elvillar) y Alto de la Huesera (Laguardia). Arkeoikuska 2010, 164-173.

Fernández Eraso, J.; Mujika-Alustiza, J.A. 2012. Dólmenes de La Rioja Alavesa: Chabola de la Hechicera (Elvillar) y Alto de la Huesera (Laguardia). Arkeoikuska 2011, 207-212.

Fernández Eraso, J.; Mujika-Alustiza, J.A., 2013a. La estación megalítica de la Rioja Alavesa: cronología, orígenes y ciclos de utilización. Zephyrus LXXI, 89-106.

Fernández Eraso, J.; Mujika-Alustiza, J.A., 2013b. El dolmen del Alto de la Huesera. Arkeoikuska 2012, 90-91.

Fernández Eraso, J.; Mujika-Alustiza, J.A., 2014. El dolmen del Alto de la Huesera. Arkeoikuska 2013, 99-103.

Fernández Medrano, D., 1948. Descubrimientos prehistóricos en la zona de Laguardia (Álava), Ikuska 110-113

Figueiredo, M.O.; Silva, T.P.; Veiga, J.P., 2008. Analysis of degradation phenomena in ancient, traditional and improved building materials of historical monuments. Applied Physics A, 92, pp. 151-154. (doi: http://dx.doi.org/10.1007/s00339-0084466-6)

Gavilán, B.; Rodríguez, Y.; Maura. R., 2013. Excavación arqueológica en el dolmen de la Fuente del Corcho (Bélmez, Córdoba). Onoba, 1, pp. 3-18.

Gutiérrez, J.M., 2008. Conservación, investigación y difusión del campo megalítico de Alberite. Experiencias de un proyecto inacabado. $\mathrm{PH}$ Boletín del Instituto Andaluz de Patrimonio Histórico, 67, pp. 170-175.

Hosking, M., 2009. Orientations of dolmens of Western Europe. Complutum, 20(2), pp. 165-175.

Ledo, F., 2016. Rescate documental de petroglifos y reconstrucción 3D del corredor dolménico de Cubillejo de Lara, Burgos. VAR (Virtual Archaeology Review), 7(14), pp. 43-52. (doi: http://dx.doi.org/10.4995/var.2016.4522)

López, E.; Mañana, P., 2013. El círculo lítico de Monte Lobeira (Vilanova de Arousa, Pontevedra) Trabajos de 2008 y 2010. Report CAPA 34, CSIC-Incipit. Santiago de Compostela, Spain. (http://hdl.handle.net/10261/83645)

López de Calle, C.; Iriarte, M.J.; Zapata, L., 2001. Análisis paleoambientales en el dolmen de Collado del Mallo (Trevijano, La Rioja). Viabilidad y trabas de la paleoecología vegetal en estructuras dolménicas. Zubía, 13, pp. 65-96.
Lozano, J.A.; Ruiz-Puertas, G.; Hódar-Correa, M.; PérezVarela, F.; Morgado, A., 2014. Prehistoric engineering and astronomy of the great Menga Dolmen (Malaga, Spain). A geometric and geoarchaeological analysis. Journal of Archaeological Science, 41, pp. 759-771. (doi: http://dx.doi.org/10.1016/j.jas.2013.10.010)

Luján, J.; Aguilella, G., 2012. Ensayo de reconstrucción virtual de un túmulo funerario: el túmulo de Mortórum (Cabanes, Castellón). VAR (Virtual Archaeology Review), 3(6), pp. 40-44.

Mañana, P., 2005. Túmulo 5 de Forno dos Mouros (Ortigueira, A Coruña). Primeiros resultados. Cuadernos de Estudios Gallegos, LII(118), pp. 39-79.

(http://hdl.handle.net/10261/26026)

Martínez-Torres, L. M.; Fernández-Eraso, J.; Mujika-Alustiza, J.A.; Rodríguez-Miranda, Á.; Valle-Melón, J.M., 2014. Geoarchaeology and construction of the La Chabola de la Hechicera megalithic tomb, Elvillar, Northern Spain. Geoarchaeology, 44, pp. 300-311.

(doi: http://dx.doi.org/10.1002/gea.21479)

Moraza, A.; Moro, I.; Mujika, J.A., 2003. Contribución al estudio de las estructuras tumulares en arqueología: entre la similitud morfológica y la disparidad de funciones. Veleia, 20, pp. 243-272.

Orengo, H.A., 2013. Combining terrestrial stereophotogrammetry, DGPS and GIS-based 3D voxel modelling in the volumetric recording of archaeological features. ISPRS Journal of Photogrammetry and Remote Sensing, 76, pp. 49-55.

(doi: http://dx.doi.org/10.1016/j.isprsjprs.2012.07.005)

Navarro, V.; Romera, L.E.; Yustres, A.; Candel, M., 2008. Mobilization analysis of the dolmen of Dombate (Nortwest Spain). Engineering Geology, 100, pp. 59-68. (doi: http://dx.doi.org/10.1016/j.engggeo.2008.03.002)

Reinosa, J.M.; Romera, L.E., 2015. Stability of megalithic structures against overturning. Journal of Cultural Heritage, 16, pp. 798-804.

(doi: http://dx.doi.org/10.1016/j.culher.2015.03.006)

Rodríguez, A.; Pérez, P.; Martínez, R., Valle, J.M., 2015. Reutilización de pares fotogramétricos de elementos arquitectónicos para la obtención de modelos 3D y ortofotografías a partir de técnicas SFM. Arqueología de la $\begin{array}{lll}\text { Arquitectura, } & \text { 12, } & \text { e24. }\end{array}$ http://dx.doi.org/10.3989/arq.arqt.2015.004)

Romão, P.M.S., Rattazzi, A., 1996. Biodeterioration on megalithic monuments. Study of lichens' colonization on Tapadão and Zumbujeiro dolmens (Southern Portugal). International Biodeterioration \& Biodegradation, pp. 23-35.

Schmitt, A.; Bizot, B., 2016. Retour d'expériences sur l'étude des trois assemblages osseux issus de sépultures collectives néolitiques. BMSAP (Bulletins et mémoires de la Société d'anthropologie de Paris), 28, pp. 190-201. (doi: http://dx.doi.org/10.1007/s13219-016-0156-7)

Valle, J.M.; Rodríguez, Á., 2010. Methodological keys for the acquisition and long-term use of photographic collections 
The International Archives of the Photogrammetry, Remote Sensing and Spatial Information Sciences, Volume XLII-5/W1, 2017 GEOMATICS \& RESTORATION - Conservation of Cultural Heritage in the Digital Era, 22-24 May 2017, Florence, Italy

representing elements of heritage. In: Fusion of Cultures. Abstracts of the XXXVIII Annual Conference on Computer Applications and Quantitative Methods in Archaeology CAA2010. pp. 175-178.

(https://addi.ehu.es/handle/10810/6987) 